TITLE:

\title{
Influence of water vapor on performance degradation and microstructural change of $(\mathrm{La}, \mathrm{Sr})(\mathrm{Co}, \mathrm{Fe}) \mathrm{O3}-\delta$ cathode
}

\section{AUTHOR(S):}

Kim, Minkyu; Muroyama, Hiroki; Matsui, Toshiaki; Eguchi, Koichi

\section{CITATION:}

Kim, Minkyu ... [et al]. Influence of water vapor on performance degradation and microstructural change of (La,Sr) (Co,Fe)O3- $\delta$ cathode. Journal of the Electrochemical Society 2019, 166(16): F1269-F1274

ISSUE DATE:

2019-11-16

URL:

http://hdl.handle.net/2433/251036

\section{RIGHT:}

This is an open access article distributed under the terms of the Creative Commons Attribution Non-Commercial No Derivatives 4.0 License (CC BY-NC-ND,

http://creativecommons.org/licenses/by-nc-nd/4.0/), which permits non-commercial reuse, distribution, and reproduction in any medium, provided the original work is not changed in any way and is properly cited. For permission for commercial reuse, please email: oa@electrochem.org. 
Journal of The Electrochemical Society

OPEN ACCESS

Influence of Water Vapor on Performance Degradation and Microstructural Change of $(\mathrm{La}, \mathrm{Sr})(\mathrm{Co}, \mathrm{Fe}) \mathrm{O}_{3-\delta}$ Cathode

To cite this article: Minkyu Kim et al 2019 J. Electrochem. Soc. 166 F1269

View the article online for updates and enhancements. 


\title{
Influence of Water Vapor on Performance Degradation and Microstructural Change of $(\mathrm{La}, \mathrm{Sr})(\mathrm{Co}, \mathrm{Fe}) \mathrm{O}_{3-\delta}$ Cathode
}

\author{
Minkyu Kim, Hiroki Muroyama, @* Toshiaki Matsui, @i) ${ }^{*, z}$ and Koichi Eguchi* \\ Department of Energy and Hydrocarbon Chemistry, Graduate School of Engineering, Kyoto University, Nishikyo-ku, \\ Kyoto 615-8510, Japan
}

\begin{abstract}
In this study, single cells employing a $\mathrm{La}_{0.6} \mathrm{Sr}_{0.4} \mathrm{Co}_{0.2} \mathrm{Fe}_{0.8} \mathrm{O}_{3-\delta}$ (LSCF) cathode were operated with a supply of humidified oxygen to the cathode at $1000^{\circ} \mathrm{C}$ for $100 \mathrm{~h}$ to investigate the influence of water vapor on the performance and microstructure of LSCF cathode. When a gaseous mixture of $20 \% \mathrm{H}_{2} \mathrm{O}-80 \% \mathrm{O}_{2}$ was supplied to the cathode, the performance of LSCF cathode continuously lowered during a discharge at $300 \mathrm{~mA} \mathrm{~cm}^{-2}$ for $100 \mathrm{~h}$. Then, the microstructures of surface and cross-section of LSCF cathode were observed by scanning electron microscopy. The surface morphology was drastically changed by the discharge operation. A SrO layer was formed at the outermost surface of cathode, indicating that the strontium segregation was accelerated by water vapor. In response to this phenomenon, the formation amount of cobalt- and/or iron-based oxides enlarged inside the electrode. These microstructural and phase changes would be responsible for the performance deterioration of LSCF cathode.

(C) The Author(s) 2019. Published by ECS. This is an open access article distributed under the terms of the Creative Commons Attribution Non-Commercial No Derivatives 4.0 License (CC BY-NC-ND, http://creativecommons.org/licenses/by-nc-nd/4.0/), which permits non-commercial reuse, distribution, and reproduction in any medium, provided the original work is not changed in any way and is properly cited. For permission for commercial reuse, please email: oa@electrochem.org. [DOI: 10.1149/2.0641915jes]
\end{abstract}

(cc) BY-NC-ND

Manuscript submitted August 9, 2019; revised manuscript received September 29, 2019. Published November 25, 2019.

Solid oxide fuel cells (SOFC) have attracted much attention as major power generation devices for the next generation because of their high energy conversion efficiency, high fuel flexibility, and low environmental load. Residential SOFC cogeneration systems have been already commercialized in Japan, ${ }^{1-3}$ but there are still some problems to be settled to ensure the reliability of SOFC systems upon long-term operation under various conditions. Thus, continuous researches and developments have been strenuously carried out.

Lanthanum strontium cobalt iron oxide, $(\mathrm{La}, \mathrm{Sr})(\mathrm{Co}, \mathrm{Fe}) \mathrm{O}_{3-\delta}$, has been applied as a cathode material due to its high mixed ionicelectronic conductivity. Oxygen is generally reduced to oxide ion at the triple phase boundary (TPB), which consists of electronic conductor, ionic conductor, and gas phase. In addition, oxygen reduction reaction (ORR) can occur over the surface of mixed ion-electron conductive materials (double phase boundary, DPB). Thus, the reaction site of ORR in the ( $\mathrm{La}, \mathrm{Sr})(\mathrm{Co}, \mathrm{Fe}) \mathrm{O}_{3-\delta}$ cathode extends from TPB to $\mathrm{DPB}$, and is more widespread than that in a conventional cathode of $(\mathrm{La}, \mathrm{Sr}) \mathrm{MnO}_{3+\delta}$. Moreover, this material exhibits good performance even at intermediate temperatures owing to its higher catalytic activity for the ORR. Low stability of $(\mathrm{La}, \mathrm{Sr})(\mathrm{Co}, \mathrm{Fe}) \mathrm{O}_{3-\delta}$, however, is a serious issue to be solved for the development of reliable SOFC stacks. This material has a low chemical compatibility with a conventional electrolyte of yttria-stabilized zirconia (YSZ); formation of high-resistive phases of $\mathrm{SrZrO}_{3}$ and $\mathrm{La}_{2} \mathrm{Zr}_{2} \mathrm{O}_{7}$ proceeds via reactions between these two components during cell fabrication processes and discharge operations. Interlayer of ceria-based oxide material is inserted as a barrier layer between the electrolyte and electrode to suppress the formation of these phases, but it is difficult to accomplish its complete suppression. ${ }^{4-6}$ Furthermore, various impurities in the supplied cathode gas can induce critical deteriorations of $(\mathrm{La}, \mathrm{Sr})(\mathrm{Co}, \mathrm{Fe}) \mathrm{O}_{3-\delta} \cdot{ }^{7-14}$ Some impurities such as chromium, sodium, silicon, and aluminum species are derived from interconnect, seal material, and thermal insulator. Water vapor and carbon dioxide in ambient air also have impacts on the cathode performance.

Water vapor is a common constituent in air, and humidity can achieve a high level depending on geographical and climatic conditions. Therefore, it is of great importance to comprehensively understand the stability of cathode upon operations under a humidified oxygen atmosphere. The influence of water vapor in the cathode gas on $(\mathrm{La}, \mathrm{Sr}) \mathrm{MnO}_{3+\delta}$ and $(\mathrm{La}, \mathrm{Sr})(\mathrm{Co}, \mathrm{Fe}) \mathrm{O}_{3-\delta}$ has been investigated so far. ${ }^{10-18}$ The performance of $(\mathrm{La}, \mathrm{Sr}) \mathrm{MnO}_{3+\delta}$ was deteriorated under humidified conditions. This was ascribable to the decomposition of

*Electrochemical Society Member.

${ }^{\mathrm{z} E}$ E-mail: matsui@elech.kuic.kyoto-u.ac.jp electrode to form $\mathrm{La}_{2} \mathrm{O}_{3}, \mathrm{SrO}$, and $\mathrm{Mn}_{2} \mathrm{O}_{3}$ over the electrode surface and at the interface with electrolyte. ${ }^{12,15,18}$ It was also reported that the $(\mathrm{La}, \mathrm{Sr}) \mathrm{MnO}_{3+\delta}$ cathode has a higher stability in the presence of water vapor than the $(\mathrm{La}, \mathrm{Sr})(\mathrm{Co}, \mathrm{Fe}) \mathrm{O}_{3-\delta}$ cathode. ${ }^{11,12}$ Liu et al. showed the performance degradation of $(\mathrm{La}, \mathrm{Sr})(\mathrm{Co}, \mathrm{Fe}) \mathrm{O}_{3-\delta}$ cathode under various amounts of water vapor $(3-10 \%)$ at $800^{\circ} \mathrm{C}$ for $1000 \mathrm{~h} .{ }^{12}$ They concluded that the observed strontium enrichment on the surface of $(\mathrm{La}, \mathrm{Sr})(\mathrm{Co}, \mathrm{Fe}) \mathrm{O}_{3-\delta}$ was responsible for the degradation. But, only limited information have been obtained yet for the deterioration of $(\mathrm{La}, \mathrm{Sr})(\mathrm{Co}, \mathrm{Fe}) \mathrm{O}_{3-\delta}$ cathode. Therefore, it is necessary to investigate the degradation mechanism upon long-term operations more detail.

In this study, then, we investigated the degradation mechanism of porous $\mathrm{La}_{0.6} \mathrm{Sr}_{0.4} \mathrm{Co}_{0.2} \mathrm{Fe}_{0.8} \mathrm{O}_{3-\delta}$ (LSCF) cathode by water vapor, especially focusing on the microstructural change. Button cells employing an LSCF cathode were operated at a high temperature of $1000^{\circ} \mathrm{C}$ under highly-humidified oxygen atmospheres $\left(10\right.$ or $\left.20 \% \mathrm{H}_{2} \mathrm{O}\right)$ for $100 \mathrm{~h}$ to accelerate microstructural changes. After the performance evaluation, the samples were analyzed by focused ion beam-scanning electron microscopy (FIB-SEM), and their microstructural change was quantified to clarify the degradation factors. This technique can provide essential information to understand the quantitative relationship among the electrode microstructure, performance, and long-term stability.

\section{Experimental}

Cell preparation.-A single cell was fabricated as follows. A disk of $8 \mathrm{~mol} \%$ yttria-stabilized zirconia (YSZ, Tosoh, $24 \mathrm{~mm}$ in diameter, $500 \mu \mathrm{m}$ in thickness) was employed as an electrolyte. NiOYSZ powder (AGC Seimi Chemical Co., Ltd.) with a volumetric ratio of Ni:YSZ $=50: 50, \mathrm{Ce}_{0.9} \mathrm{Gd}_{0.1} \mathrm{O}_{2-\delta}$ (GDC, Shin-Etsu Chemical Co., Ltd.), and $\mathrm{La}_{0.6} \mathrm{Sr}_{0.4} \mathrm{Co}_{0.2} \mathrm{Fe}_{0.8} \mathrm{O}_{3-\delta}$ (LSCF, Kusaka Rare Metal Products Co., Ltd.) were used as an anode, an interlayer, and a cathode, respectively. Carbon (Asahi Carbon Co., Ltd, SUNBLACK 220) was added to the NiO-YSZ powder to be $10 \mathrm{wt} \%$. These powders of cell components were mixed with polyethylene glycol 400 (Wako Chemical Industries) to form slurry. The resultant slurry of NiO-YSZ was screen-printed onto one side of the YSZ disk, and subsequently fired at $1400^{\circ} \mathrm{C}$ for $5 \mathrm{~h}$. Then, the GDC slurry was screen-printed on the other side of the disk, and calcined at $1350^{\circ} \mathrm{C}$ for $10 \mathrm{~h}$. After that, the LSCF slurry was coated on the GDC layer and subsequently fired at $1050^{\circ} \mathrm{C}$ for $5 \mathrm{~h}$. Reference electrode of platinum wire was attached to surround the side edge of the YSZ disk and fixed by a platinum paste (N.E. Chemcat Co., U-3402), followed by firing at $900^{\circ} \mathrm{C}$ for $2 \mathrm{~h}$. The single cell was sandwiched by alumina tubes with gold rings as 
sealing materials. Before electrochemical measurements, NiO-YSZ was reduced under a hydrogen atmosphere at $1000^{\circ} \mathrm{C}$.

Cell operation.-Gaseous mixtures of $3 \% \mathrm{H}_{2} \mathrm{O}-97 \% \mathrm{H}_{2}$ and $x \%$ $\mathrm{H}_{2} \mathrm{O}-(100-x) \% \mathrm{O}_{2}(x=0,10,20)$ were supplied to the anode and cathode, respectively, with a total flow rate of $100 \mathrm{~mL} \mathrm{~min}^{-1}$. The mixed gas was prepared by bubbling pure hydrogen or oxygen gas through water, which was kept at desired temperatures. The single cell was discharged at a constant current density of $300 \mathrm{~mA} \mathrm{~cm}^{-2}$ for $100 \mathrm{~h}$ at $1000^{\circ} \mathrm{C}$. Electrochemical impedance spectra were recorded every $20 \mathrm{~h}$ during the cell operation, in a frequency range from $0.5 \mathrm{MHz}$ to $0.1 \mathrm{~Hz}$ with an $\mathrm{AC}$ amplitude of $10 \mathrm{mV}$ under the open circuit condition. The electrochemical measurements were conducted using CellTest system (Solartron Analytical, potentiostat/galvanostat 1470E and frequency response analyzer 1455). After the cell operation, the cell was cooled down to room temperature in $\mathrm{N}_{2}$.

Characterization.-Microstructural observations and elemental analyses of LSCF cathode were carried out by using a field emissionscanning electron microscope (FE-SEM, NVision 40, Carl ZeissSIINT) equipped with an energy dispersive X-ray spectrometer (EDX, INCAxact, Oxford Instruments). Microstructure of cathode layer and interlayer was also quantitatively analyzed by using a focused ion beam-scanning electron microscope (FIB-SEM, NX9000, HITACHI). For a 3D reconstruction of these layers, the cell was infiltrated with an epoxy resin, and then the cross-section of layers was observed. Two dimensional SEM pictures $(x-z$ plane) were collected along $y$-direction with a spacing of ca. $45 \mathrm{~nm}$ by milling-and-see operations. The 3D microstructure was reconstructed in a computational field by aligning regularly spaced cross-sectional SEM images, and then microstructural parameters were quantified. The more detailed description of analysis using FIB-SEM was reported by Iwai et al. ${ }^{19}$

Crystalline phase in the cathode was analyzed by X-ray diffraction (XRD, Rigaku, Ultima IV X-ray diffractometer) equipped with a highspeed detector (D/tex Ultra). A piece of sample was fixed using a clay so that the cathode surface could be irradiated with X-ray. The measurement was performed in $20-80^{\circ}$ at $40 \mathrm{kV}$ and $40 \mathrm{~mA}$ with a scanning rate of $20^{\circ} \mathrm{min}^{-1}$.

Thermodynamic calculation was conducted by using MALT for Windows with gem and CHD (Kagaku Gijutsu-Sha) to evaluate molar fractions of volatile strontium, cobalt, and iron species under humidified conditions at $1000^{\circ} \mathrm{C}$ and $1 \mathrm{~atm}$. A $100 \mathrm{~mol}$ of $\mathrm{H}_{2} \mathrm{O}-\mathrm{O}_{2}$ mixture and a $1 \mathrm{~mol}$ of $\mathrm{SrO}$ or $\mathrm{CoFe}_{2} \mathrm{O}_{4}$ were assumed to exist as a gas and solid phases, respectively, at the initial state of system.

\section{Results and Discussion}

Discharge operation with a supply of $\mathrm{H}_{2} \mathrm{O}-\mathrm{O}_{2}$ to the cathode.The influence of the humidity in the cathode gas on the performance stability of LSCF electrode was investigated by discharging the single cell of Ni-YSZ|YSZ|GDC|LSCF at $300 \mathrm{~mA} \mathrm{~cm}^{-2}$ for $100 \mathrm{~h}$ at $1000^{\circ} \mathrm{C}$. Time courses of ohmic and polarization resistances between the LSCF cathode and the reference electrode are shown in Figure 1. The ohmic resistance drastically dropped from the beginning of discharge up to ca. $20 \mathrm{~h}$ in $100 \% \mathrm{O}_{2}$ and $10 \% \mathrm{H}_{2} \mathrm{O}-90 \% \mathrm{O}_{2}$. Similar behavior was observed previously. ${ }^{6}$ This might be attributed to the current passage effect; an improvement of the contact condition between LSCF and GDC is one of the reasons. The ohmic resistance in $20 \% \mathrm{H}_{2} \mathrm{O}-80 \% \mathrm{O}_{2}$, however, showed no remarkable decrease and kept at a nearly stable value within the elapsed time. This implied that the water vapor in the cathode gas should induce some negative effects, which canceled the reduction of ohmic resistance at the initial stage. For the polarization resistance, a gradual decrease was confirmed in dry $\mathrm{O}_{2}$. The current passage effect also positively contributed to this resistive component. But, the resistance remained almost unchanged at $10 \%$ of humidity. Moreover, the higher humidity provided a continuous increase of polarization resistance within $100 \mathrm{~h}$. Accordingly, the water vapor in the cathode gas was one of the factors deteriorating the LSCF cathode.

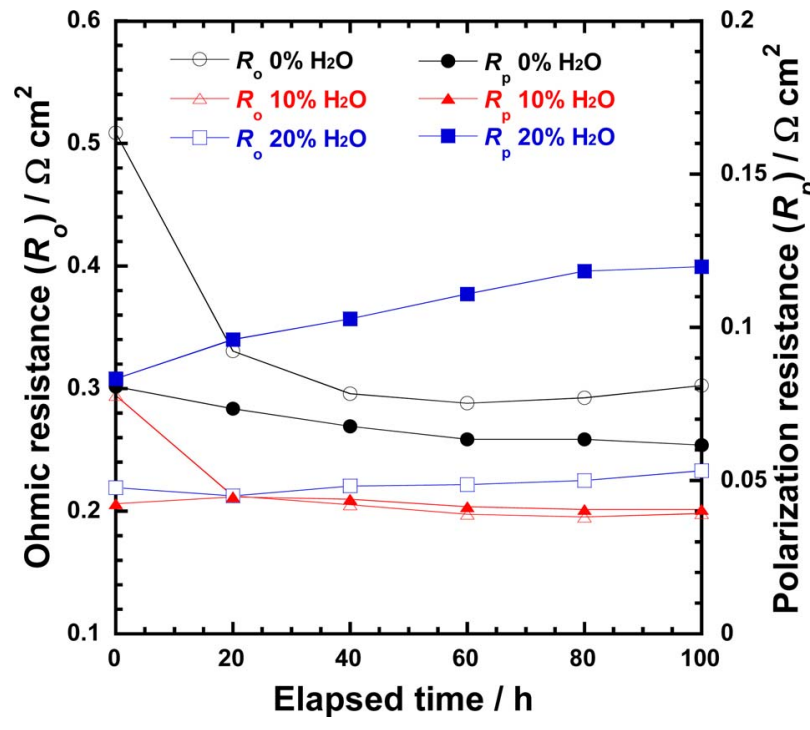

Figure 1. Time courses of ohmic and polarization resistances of LSCF cathode during discharge at $300 \mathrm{~mA} \mathrm{~cm}^{-2}$ for $100 \mathrm{~h}$ at $1000^{\circ} \mathrm{C}$. Cathode gas: $x \% \mathrm{H}_{2} \mathrm{O}$ $(100-x) \% \mathrm{O}_{2}(x=0,10,20)$; Anode gas: 3\% $\mathrm{H}_{2} \mathrm{O}-97 \% \mathrm{H}_{2}$

Microstructure and elemental distribution of LSCF cathode surface.-The LSCF cathode surface before and after discharge operations was observed by FE-SEM to clarify its morphological change depending on the humidity in the supplied gas. Figure 2 shows SEM images of the cathode surface. LSCF particles less than $1 \mu \mathrm{m}$ were rounded in the initial electrode, and little change was observed after the discharge in dry $\mathrm{O}_{2}$. On the other hand, some angular particles seemed to newly form over the LSCF particles during the operation in $10 \% \mathrm{H}_{2} \mathrm{O}-90 \% \mathrm{O}_{2}$. Further increase in the humidity promoted the growth of such particles, which covered the surface of LSCF particles as can be seen in Figure 2d.

Elements in the vicinity of cathode surface observed in Figure 2 was examined by EDX analysis. Atomic percentages of metal cation at the LSCF surface are summarized in Table I. The strontium concentration increased with rising humidity, accompanied by a decrease in the ratio of other metal elements. In response, the ratio of strontium ion in the A site cation $(\mathrm{Sr} /(\mathrm{La}, \mathrm{Sr})$ ratio $)$ and the ratio of A site cation to B site cation $((\mathrm{La}, \mathrm{Sr}) /(\mathrm{Co}, \mathrm{Fe})$ ratio $)$ for the sample operated in $20 \%$ $\mathrm{H}_{2} \mathrm{O}-80 \% \mathrm{O}_{2}$ were much higher than nominal ones. This phenomenon
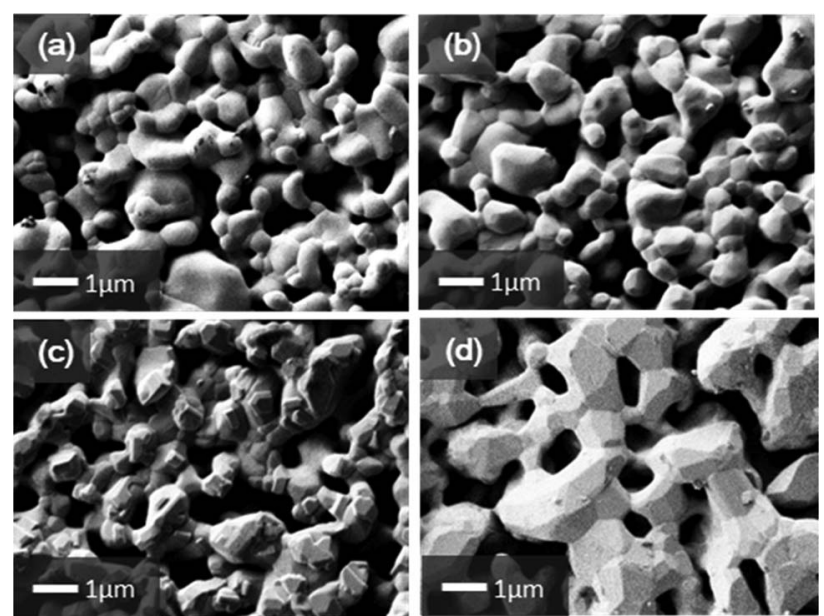

Figure 2. SEM images of LSCF cathode surface (a) before and (b-d) after discharge at $300 \mathrm{~mA} \mathrm{~cm}^{-2}$ for $100 \mathrm{~h}$ at $1000^{\circ} \mathrm{C}$ with a supply of (b) $100 \% \mathrm{O}_{2}$, (c) $10 \% \mathrm{H}_{2} \mathrm{O}-90 \% \mathrm{O}_{2}$, and (d) $20 \% \mathrm{H}_{2} \mathrm{O}-80 \% \mathrm{O}_{2}$ to the cathode. 
Table I. Atomic percentages of elements at the LSCF surface before and after discharge.

\begin{tabular}{|c|c|c|c|c|c|c|}
\hline \multirow[b]{3}{*}{ Condition } & \multicolumn{4}{|c|}{ Atomic percentage $^{\mathrm{a}}(\%)$} & \multirow[b]{3}{*}{$\mathrm{Sr} /(\mathrm{La}, \mathrm{Sr})$ ratio } & \multirow[b]{3}{*}{$(\mathrm{La}, \mathrm{Sr}) /(\mathrm{Co}, \mathrm{Fe})$ ratio } \\
\hline & \multicolumn{2}{|c|}{ A site } & \multicolumn{2}{|c|}{ B site } & & \\
\hline & $\mathrm{La}$ & $\mathrm{Sr}$ & Co & $\mathrm{Fe}$ & & \\
\hline Before discharge & 15.8 & 7.5 & 4.8 & 21.2 & 0.32 & 0.90 \\
\hline $100 \% \mathrm{O}_{2}$ & 16.4 & 7.3 & 4.9 & 22.0 & 0.31 & 0.88 \\
\hline $10 \% \mathrm{H}_{2} \mathrm{O}-90 \% \mathrm{O}_{2}$ & 14.9 & 10.7 & 4.2 & 19.7 & 0.42 & 1.07 \\
\hline $20 \% \mathrm{H}_{2} \mathrm{O}-80 \% \mathrm{O}_{2}$ & 7.5 & 17.5 & 2.6 & 6.5 & 0.70 & 2.74 \\
\hline
\end{tabular}

${ }^{\text {a }}$ These values were evaluated from EDX analysis. Rest of atomic percentages is derived from oxygen.

would be attributable to the strontium segregation from the lattice of LSCF perovskite-type structure. The strontium segregation has been observed for perovskite-type oxides containing strontium cation in the A site such as $(\mathrm{La}, \mathrm{Sr}) \mathrm{MnO}_{3+\delta}$ and $(\mathrm{La}, \mathrm{Sr})(\mathrm{Co}, \mathrm{Fe}) \mathrm{O}_{3-\delta}$, which is one of the degradation factors for the cathode of SOFCs. ${ }^{18,20-22}$

Elemental analysis and phase identification for an LSCF cathode.-The SEM observation of cathode surface indicated that newly-formed compounds were deposited over the surface of LSCF particles under humidified oxygen atmospheres. Then, the microstructure of cathode operated in $20 \% \mathrm{H}_{2} \mathrm{O}-80 \% \mathrm{O}_{2}$ was examined in more detail, and its cross-sectional SEM image is depicted in Figure 3. Some regions with different contrasts were confirmed, implying that the cathode layer was composed of multiple phases. Elemental analysis was conducted at some points in Figure 3, and the atomic ratio at each point is summarized in Table II. The metal elements of lanthanum, strontium, cobalt, and iron were detected at Point 1 . Since their ratio was comparable to the nominal composition of LSCF, the bright gray part corresponds to the framework of LSCF. The dark gray part inside the electrode (Point 2) was mainly composed of cobaltand/or iron-based oxides (Co,Fe-based oxides) such as $\mathrm{CoFe}_{2} \mathrm{O}_{4}$. It is known that the formation of such secondary phases is triggered by the segregation and diffusion of strontium ion from the A site in the $(\mathrm{La}, \mathrm{Sr})(\mathrm{Co}, \mathrm{Fe}) \mathrm{O}_{3-\delta}$ perovskite structure. ${ }^{23}$ Among the dark gray regions, a $1 \mu \mathrm{m}$-thick layer was located at the electrode surface. Such layer corresponds to the compounds covering the LSCF particles observed in Figure 2. According to the composition at Point 3 , this layer was supposedly identical to strontium oxide. Such strontium oxide layer was responsible for the high strontium concentration

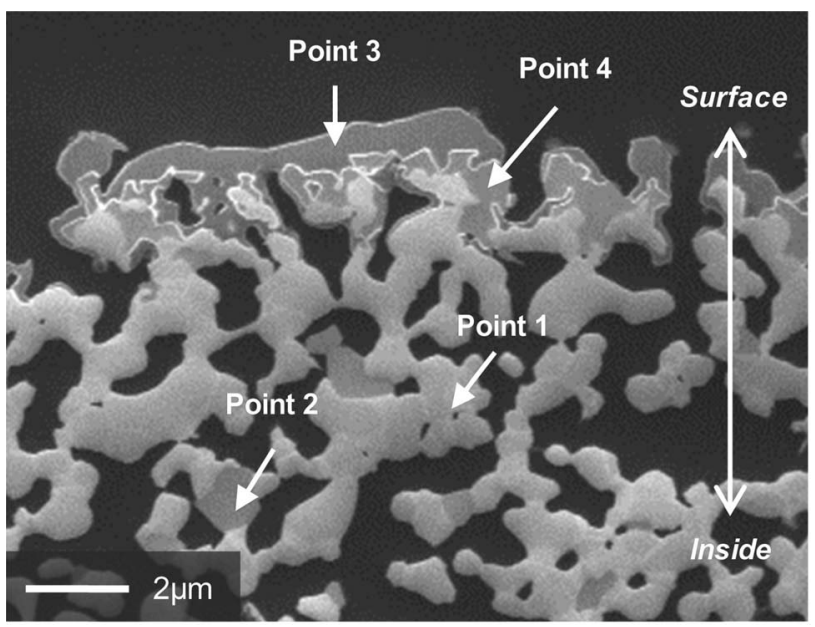

Figure 3. Cross-sectional SEM image of LSCF cathode after discharge at $300 \mathrm{~mA} \mathrm{~cm}^{-2}$ for $100 \mathrm{~h}$ at $1000^{\circ} \mathrm{C}$ with a supply of $20 \% \mathrm{H}_{2} \mathrm{O}-80 \% \mathrm{O}_{2}$ to the cathode. near the surface shown in Table I. Furthermore, cobalt- and iron-rich parts were also widely distributed under the strontium oxide layer (Point 4).

Crystalline phases were studied for the LSCF cathodes before and after discharge in dry and humidified atmospheres. XRD patterns of these cathodes are shown in Figure 4. The pattern of as-prepared sample consisted of LSCF and GDC phases. No specific change in the crystalline phases of cathode was confirmed after discharge in $100 \%$ $\mathrm{O}_{2}$. In contrast, the $\mathrm{SrO}$ phase was newly formed in the sample operated in $10 \% \mathrm{H}_{2} \mathrm{O}-90 \% \mathrm{O}_{2}$. Furthermore, the number of detectable diffraction peak of $\mathrm{SrO}$ phase increased accompanied by an emergence of unknown phases after discharge at the higher humidity. These results indicated that the formation amount of $\mathrm{SrO}$ and unknown compounds increased with a rise of humidity in the cathode gas.

Accordingly, it was clarified that the SrO layer covered the LSCF particles during discharge operations under humidified conditions. The water vapor in the cathode gas facilitated the segregation of strontium from the LSCF lattice. In response, the $\mathrm{Co}$, Fe-based oxides were formed, as indicated by the EDX analysis. But the corresponding phases were not clearly detectable by the XRD measurement. Since the unknown phases also existed in the cathode operated in $20 \% \mathrm{H}_{2} \mathrm{O}$ $80 \% \mathrm{O}_{2}$, these may be assigned to the $\mathrm{Co}, \mathrm{Fe}$-based oxides.

FIB-SEM analysis for an LSCF cathode.-The LSCF cathodes were analyzed by FIB-SEM for the cells discharged in $100 \% \mathrm{O}_{2}$ and $20 \% \mathrm{H}_{2} \mathrm{O}-80 \% \mathrm{O}_{2}$. 3D microstructural model including whole region in the cathode thickness direction was reconstructed, followed by the evaluation of some structural parameters. Figure 5 depicts the $3 \mathrm{D}$ reconstructed phases of $\mathrm{SrO}$ and $\mathrm{Co}$,Fe-based oxides in the $\mathrm{LSCF}$ cathodes, and the corresponding volumes are summarized in Table III. The strontium oxide was formed more remarkably upon the operation at $20 \%$ of humidity. In particular, this oxide was obviously localized at the outermost surface of cathode in the case of higher humidity, which agreed well with the phenomenon observed in Figure 3. The particles of $\mathrm{Co}, \mathrm{Fe}$-based oxides seemed to be distributed homogeneously in the cathode layer under the dry condition. The formation of these oxides was facilitated by the humidified oxygen; the operation at $20 \%$ of humidity resulted in twice amount of $\mathrm{Co}, \mathrm{Fe}$-based oxides compared with the dry condition. Moreover, as in the case of SrO, a large amount of $\mathrm{Co}, \mathrm{Fe}$-based oxides was confirmed in the vicinity of cathode surface.

Table II. Atomic percentages of elements at Points 1-4 of LSCF cathode in Figure 3.

\begin{tabular}{ccccccc} 
& \multicolumn{4}{c}{ Atomic percentage (at.\%) } & \\
\cline { 2 - 6 } Position & $\mathrm{La}$ & $\mathrm{Sr}$ & $\mathrm{Co}$ & $\mathrm{Fe}$ & $\mathrm{O}$ & Main phase \\
\hline Point 1 & 16 & 8.1 & 3.5 & 20 & 53 & LSCF \\
Point 2 & 0.7 & 0 & 19 & 26 & 54 & Co,Fe-based oxides \\
Point 3 & 3.6 & 26 & 0 & 0 & 71 & SrO \\
Point 4 & 2.2 & 6.0 & 13 & 24 & 55 & Co,Fe-based oxides
\end{tabular}


$(\nabla) \mathrm{La}_{0.6} \mathrm{Sr}_{0.4} \mathrm{Co}_{0.2} \mathrm{Fe}_{0.8} \mathrm{O}_{3-\delta} \Leftrightarrow \mathrm{Ce}_{0.9} \mathrm{Gd}_{0.1} \mathrm{O}_{2-\delta}$ (•) SrO (॰) unknown $\left({ }^{*}\right)$ clay

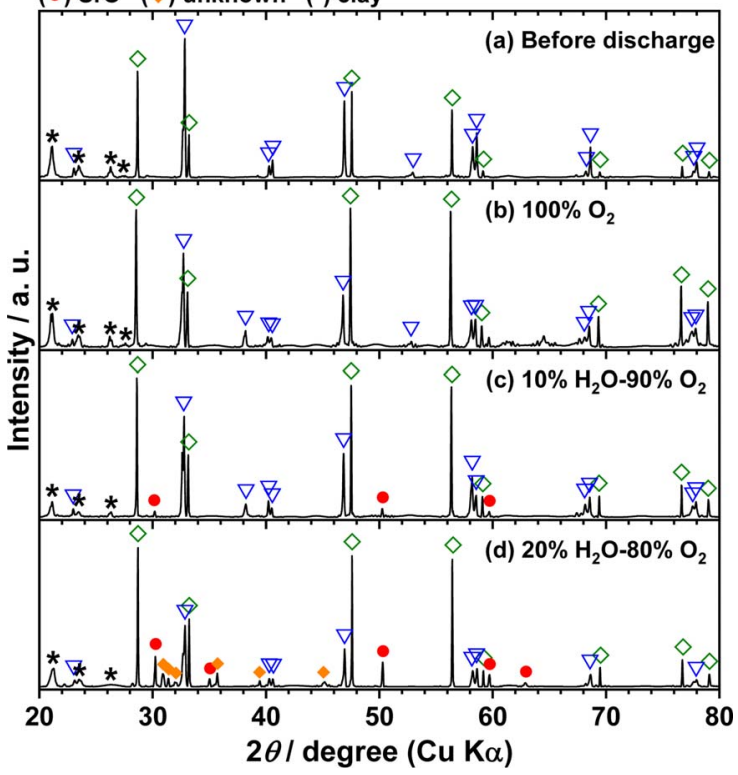

Figure 4. XRD patterns of LSCF cathode (a) before and (b-d) after discharge at $300 \mathrm{~mA} \mathrm{~cm}^{-2}$ for $100 \mathrm{~h}$ at $1000^{\circ} \mathrm{C}$ with a supply of (b) $100 \% \mathrm{O}_{2}$, (c) $10 \%$ $\mathrm{H}_{2} \mathrm{O}-90 \% \mathrm{O}_{2}$, and (d) $20 \% \mathrm{H}_{2} \mathrm{O}-80 \% \mathrm{O}_{2}$ to the cathode.
It was reported that the electronic conductivity of $\mathrm{SrO}$ and $\mathrm{CoFe}_{2} \mathrm{O}_{4}$ is ca. $10^{-4} \mathrm{~S} \mathrm{~cm}^{-1}$ and ca. $10^{-2} \mathrm{~S} \mathrm{~cm}^{-1}$, respectively, at $800^{\circ} \mathrm{C}^{24,25}$ Since the conductivity of LSCF is ca. $10^{2} \mathrm{~S} \mathrm{~cm}^{-1},{ }^{26,27}$ these secondary phases served as inhibitors and could break the electronic conduction path in the cathode layer, resulting in the negative effect on the ohmic resistance.

According to the numerical analyses, in the porous cathode layer employing mixed ionic-electronic conductors, the oxygen reduction reaction proceeds within a 5-20- $\mu \mathrm{m}$-thick region from the interface with an electrolyte, and the residual part away from this region mainly serves as a current collecting layer. ${ }^{28,29}$ In this study, the prepared cathode layer was ca. $30 \mu \mathrm{m}$ in thickness. Thus, it was assumed that the secondary phases formed at the surface did not significantly affect the ORR, and the increase in polarization resistance was ascribable to the quantitative change in reaction sites. Then, the LSCF surface area, TPB length, and DPB area in ca. $15-\mu$ m-thick region from the interface were evaluated, as also summarized in Table III. The TPB length corresponds to an electrochemically-active site because this length was calculated based on the LSCF, GDC, and gas phases connecting with a certain plane of analyzed rectangular solid. The double phase boundary is defined as the interface area of LSCF and gas phases, and can be also an active area for the ORR due to the mixed ion-electron conductive property of LSCF, as mentioned above. The TPB length and DPB area under the humidified condition were ca. 11-16\% smaller than those in the dry condition. Moreover, the water vapor in the cathode gas was likely to promote the agglomeration of LSCF particles. Thus, the deterioration of contact state between LSCF and GDC layers should result in the shorter TPB length. The DPB area was obviously smaller than the LSCF surface area for both conditions, implying that (a) $\mathrm{SrO}, 100 \% \mathrm{O}_{2}$

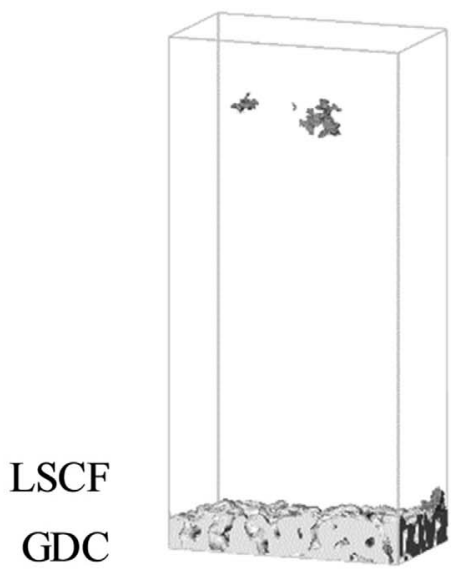

(c) Co,Fe-based oxides, $100 \% \mathrm{O}_{2}$
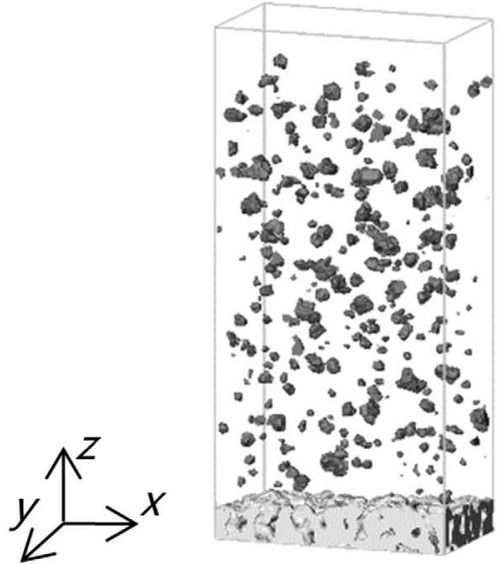

(b) $\mathrm{SrO}, 20 \% \mathrm{H}_{2} \mathrm{O}-80 \% \mathrm{O}_{2}$

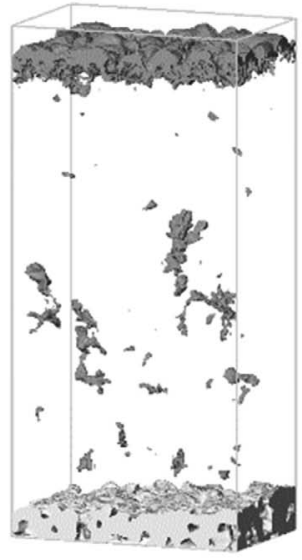

(d) Co,Fe-based oxides, $20 \% \mathrm{H}_{2} \mathrm{O}-80 \% \mathrm{O}_{2}$

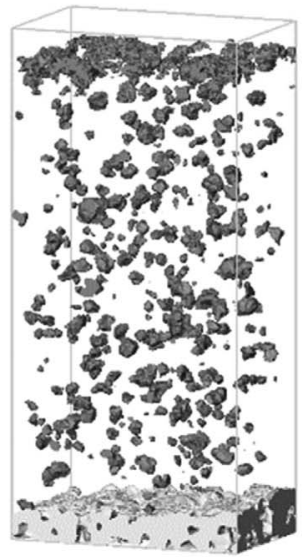

Figure 5. 3D reconstructed phases of (a,b) $\mathrm{SrO}$ and (c,d) $\mathrm{Co}, \mathrm{Fe}-$ based oxides in the LSCF cathode after discharge at $300 \mathrm{~mA} \mathrm{~cm}^{-2}$ for $100 \mathrm{~h}$ at $1000^{\circ} \mathrm{C}$ with a supply of $(\mathrm{a}, \mathrm{c}) 100 \% \mathrm{O}_{2}$ and (b,d) $20 \%$ $\mathrm{H}_{2} \mathrm{O}-80 \% \mathrm{O}_{2}$ to the cathode. 


\footnotetext{
Table III. SrO volume, Co,Fe-based oxides volume, LSCF surface area, DPB area, and TPB length for the cells discharged in $100 \% \mathrm{O}_{2}$ and $20 \%$ $\mathrm{H}_{2} \mathrm{O}-80 \% \mathrm{O}_{2}$.
}

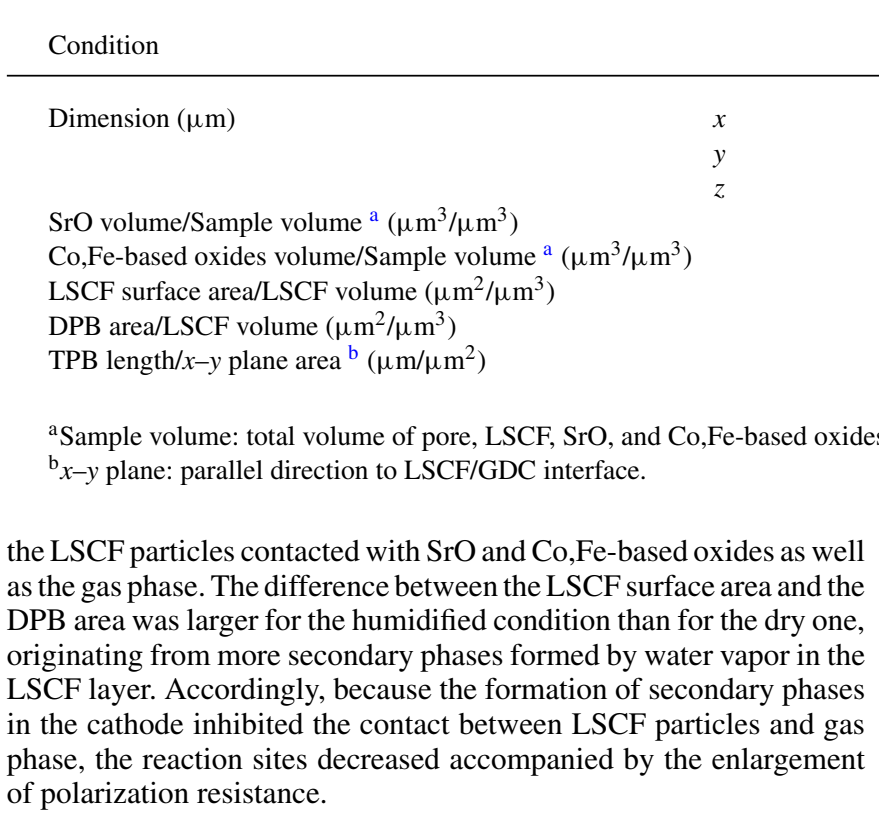

Volatility characteristics of strontium, cobalt, and iron species.Molar fraction of strontium, cobalt, and iron volatile species in humidified atmospheres at high temperatures was estimated by a thermodynamic calculation to investigate the formation mechanism of secondary phases. It was assumed that a $1 \mathrm{~mol}$ of $\mathrm{SrO}$ or $\mathrm{CoFe}_{2} \mathrm{O}_{4}$ initially exists in a $100 \mathrm{~mol}$ of $\mathrm{H}_{2} \mathrm{O}-\mathrm{O}_{2}$ gas phase. Figure 6 shows molar fraction of strontium, cobalt, and iron volatile species in $\mathrm{H}_{2} \mathrm{O}-\mathrm{O}_{2}$ atmospheres at $1000^{\circ} \mathrm{C}$. For each element, the molar fraction of hydroxide vapor is extremely higher than that of oxide vapor. Among them, the volatile strontium hydroxide, $\operatorname{Sr}(\mathrm{OH})_{2}$, the most readily forms in the whole range of $\mathrm{H}_{2} \mathrm{O}$ concentrations. The molar ratio of volatile $\mathrm{Sr}(\mathrm{OH})_{2}$ increases by one order of magnitude from $0 \%$ to $10 \%$ of $\mathrm{H}_{2} \mathrm{O}$, followed by a gradual increase with a further rise in humidity. These results indicate that $\mathrm{Sr}(\mathrm{OH})_{2}$ formed from $\mathrm{SrO}$ was the most

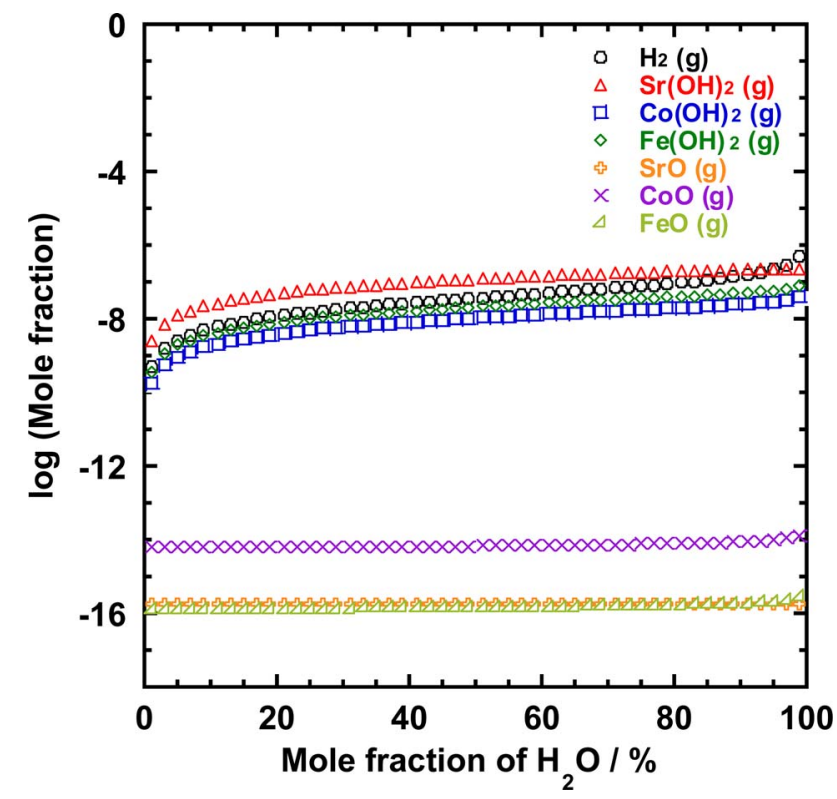

Figure 6. Molar fraction of strontium, cobalt, and iron volatile species in $\mathrm{H}_{2} \mathrm{O}-\mathrm{O}_{2}$ atmosphere at $1000^{\circ} \mathrm{C}$. volatile compound in the cathode during discharge operations. Thus, $\mathrm{SrO}$ derived from the strontium segregation reacted with water vapor to form the volatile $\mathrm{Sr}(\mathrm{OH})_{2}$, and then its vapor should diffuse to the cathode surface to deposit as the $\mathrm{SrO}$ layer. Because of the increase in the molar ratio of $\mathrm{Sr}(\mathrm{OH})_{2}$ with a rise of humidity, the accumulation of $\mathrm{SrO}$ would be remarkable under higher humidified conditions, as shown in Figure 2. In contrast, compared with $\mathrm{SrO}$, the $\mathrm{Co}, \mathrm{Fe}-$ based oxides are more stable in the solid state under $\mathrm{H}_{2} \mathrm{O}-\mathrm{O}_{2}$ atmospheres. Thus, after the strontium segregation from LSCF, the residual cobalt and iron species existed as solid oxides inside the electrode.

\section{Conclusions}

The Ni-YSZ|YSZ|GDC|LSCF single cells were discharged with a supply of humidified oxygen gas at $300 \mathrm{~mA} \mathrm{~cm}{ }^{-2}$ for $100 \mathrm{~h}$ at $1000^{\circ} \mathrm{C}$. After discharge, the cathode was quantitatively analyzed by the FIB-SEM technique. The water vapor in the supplied gas provided the negative effect on the ohmic and polarization resistances of cathode. This result was mainly ascribable to the newly-formed phases in the electrode. The segregation of strontium from the LSCF lattice was facilitated by water vapor, resulting in the formation of $\mathrm{SrO}$ and $\mathrm{Co}, \mathrm{Fe}$-based oxides at the surface and inside of cathode. These compounds inhibited the electron conduction due to their low conductivity. Moreover, these secondary phases decreased the contact area between LSCF and gas phase, which serves as the reaction site for the electrochemical ORR. The thermodynamic calculation indicated that $\mathrm{Sr}(\mathrm{OH})_{2}$ derived from $\mathrm{SrO}$ was the most volatile species in the cathode under humidified oxygen atmospheres. Thus, the volatile $\mathrm{Sr}(\mathrm{OH})_{2}$, which was formed from the reaction between water vapor and $\mathrm{SrO}$ segregated from LSCF, diffused to the electrode surface to form the SrO layer. Consequently, the water vapor in the cathode gas promoted the formation of secondary phases, resulting in the degradation of LSCF electrode.

\section{Acknowledgments}

This work was supported by the New Energy and Industrial Technology Development Organization (NEDO), Japan (Development of System and Elemental Technology on Solid Oxide Fuel Cell Project).

\section{ORCID}

Hiroki Muroyama (1D https://orcid.org/0000-0002-5026-2178 Toshiaki Matsui (D) https://orcid.org/0000-0003-1584-0304

\section{References}

1. K. Horiuchi, ECS Trans., 57, 3 (2013)

2. H. Yokokawa, ECS Trans., 57, 299 (2013).

3. M. Suzuki, Y. Takuwa, S. Inoue, and K. Higaki, ECS Trans., 57, 309 (2013) 
4. N. Jordan, W. Assenmacher, S. Uhlenbruck, V. A. C. Haanappel, H. P. Buchkremer, D. Stöver, and W. Mader, Solid State Ionics, 179, 919 (2008).

5. J. C. De Vero, K. Develos-Bagarinao, H. Kishimoto, T. Ishiyama, K. Yamaji, T. Horita, and H. Yokokawa, J. Electrochem. Soc., 164, F259 (2017).

6. T. Matsui, M. Komoto, H. Muroyama, K. Kishida, H. Inui, and K. Eguchi, J. Power Sources, 312, 80 (2016).

7. R. A. Budiman, K. D. Bagarinao, S. S. Liu, D. H. Cho, T. Ishiyama, H. Kishimoto, K. Yamaji, T. Horita, and H. Yokokawa, J. Electrochem. Soc., 165, F1206 (2018).

8. M. Perz, E. Bucher, C. Gspan, J. Waldhäusl, F. Hofer, and W. Sitte, Solid State Ionics, 288, 22 (2016)

9. Z. Zhao, L. Liu, X. Zhang, W. Wu, B. Tu, D. Cui, D. Ou, and M. Cheng, Int. J. Hydrogen Energy, 38, 15361 (2013).

10. J. Nielsen, A. Hagen, and Y. L. Liu, Solid State Ionics, 181, 517 (2010).

11. Y. L. Huang, C. Pellegrinelli, and E. D. Wachsman, J. Electrochem. Soc., 163, F171 (2016).

12. R. R. Liu, S. H. Kim, S. Taniguchi, T. Oshima, Y. Shiratori, K. Ito, and K. Sasaki, J. Power Sources, 196, 7090 (2011)

13. S. Y. Lai, D. Ding, M. Liu, M. Liu, and F. M. Alamgir, ChemSusChem, 7, 3078 (2014)

14. N. Niania, R. Podor, T. B. Britton, C. Li, S. J. Cooper, N. Svetkov, S. Skinner, and J. Kilner, J. Mater. Chem. A, 6, 14120 (2018).

15. S. H. Kim, K. B. Shim, C. S. Kim, J. T. Chou, T. Oshima, Y. Shiratori, K. Ito, and K. Sasaki, J. Fuel Cell Sci. Technol., 7, 021011 (2010).
16. A. Hagen, K. Neufeld, and Y. L. Liu, J. Electrochem. Soc., 157, B1343 (2010).

17. J. Nielsen and M. Mogensen, Solid State Ionics, 189, 74 (2011).

18. B. Hu, M. Keane, M. K. Mahapatra, and P. Singh, J. Power Sources, 248, 196 (2014).

19. H. Iwai, N. Shikazono, T. Matsui, H. Teshima, M. Kishimoto, R. Kishida, D. Hayashi, K. Matsuzaki, D. Kanno, M. Saito, H. Muroyama, K. Eguchi, N. Kasagi, and H. Yoshida, J. Power Sources, 195, 955 (2010).

20. D. Oh, D. Gostovic, and E. D. Wachsman, J. Mater. Res., 27, 1992 (2012).

21. H. Wang, K. J. Yakal-Kremski, T. Yeh, G. M. Rupp, A. Limbeck, J. Fleig, and S. A. Barnett, J. Electrochem. Soc., 163, F581 (2016).

22. H. Wang, H. Sumi, and S. A. Barnett, Solid State Ionics, 323, 85 (2018).

23. G. Ch. Kostogloudis, G. Tsiniarakis, and Ch. Ftikos, Solid State Ionics, 135, 529 (2000).

24. N. Surplice, Br. J. Appl. Phys., 17, 175 (1966).

25. L. Ajroudi, N. Mliki, L. Bessais, V. Madigou, S. Villain, and Ch. Lerouxet, Mater. Res. Bull., 59, 49 (2014).

26. L.-W. Tai, M. M. Nasrallah, H. U. Anderson, D. M. Sparlin, and S. R. Sehlin, Solid State Ionics, 76, 273 (1995).

27. G. Ch. Kostogloudis and Ch. Ftikos, Solid State Ionics, 126, 143 (1999).

28. K. Matsuzaki, N. Shikazono, and N. Kasagi, J. Power Sources, 196, 3073 (2011).

29. A. Häffelin, J. Joos, M. Ender, A. Weber, and E. Ivers-Tiffée, J. Electrochem. Soc., 160, F867 (2013). 